\title{
Need Analysis of Academic Writing Teaching Model Based on Process-genre Approach: What Do They Really Need?
}

\author{
Helaluddin*, Muhammad Arifin Ahmad, Anshari \\ Department of Education, Universitas Negeri Makassar, Indonesia
}

Received June 28, 2020; Revised August 6, 2020; Accepted September 11, 2020

\section{Cite This Paper in the following Citation Styles}

(a): [1] Helaluddin, Muhammad Arifin Ahmad, Anshari , "Need Analysis of Academic Writing Teaching Model Based on Process-genre Approach: What Do They Really Need?," Universal Journal of Educational Research, Vol. 8, No. 10, pp. 4728 - 4735, 2020. DOI: 10.13189/ujer.2020.081043.

(b): Helaluddin, Muhammad Arifin Ahmad, Anshari (2020). Need Analysis of Academic Writing Teaching Model Based on Process-genre Approach: What Do They Really Need?. Universal Journal of Educational Research, 8(10), 4728 4735. DOI: 10.13189/ujer.2020.081043.

Copyright $\bigcirc 2020$ by authors, all rights reserved. Authors agree that this article remains permanently open access under the terms of the Creative Commons Attribution License 4.0 International License

\begin{abstract}
This study aims to investigate the needs of students and lecturers in writing instructions using the process genre approach. Besides, this research is also based on facts which reveal that decision making on learning objectives is only taken from the curriculum and syllabus review used. But unfortunately, the preference of students and lecturers for learning needs is actually ignored. The method used in this study is a qualitative method using questionnaires and interviews as research instruments. The number of participants in this study was 3 Indonesian language lecturers and 65 students at the State Islamic University of Sultan Maulana Hasanuddin Banten. The participants of the students were selected by using a purposive random sampling technique. The results showed that the need for a writing learning model design using the process genre approach. Specifically, the findings of this study include several aspects needed by students and lecturers, namely: (1) a comprehensive learning approach involving students, colleagues, and lecturers, (2) writing assessment must cover broader aspects, and (3) the need for publication as part of the writing activity. Furthermore, the syntax in the learning model based on the needs analysis is: (1) recognize the form of the text, (2) analyze the text, (3) discuss the text, (4) write the text independently, (5) finalize the text, and (6) publish the text.
\end{abstract}

Keywords Need Analysis, Academic Writing, Process Genre Approach

\section{Introduction}

In general, writing instruction is indeed one of its challenges for teachers. It is caused by the level of problems that are considered quite heavy for educators, especially in tertiary institutions [1], [2]. Another thing that makes writing instruction as one of the most challenging learning is the need for an analytical argument that must be taught to students [3].

The issue of learning to write has become a global problem and has even become mainstream in the disciplines of applied linguistics in the last few decades. Not only in learning foreign languages, but students also find difficulties in learning to write Indonesian [4]. In other words, writing is considered a problematic language skill even, for native speakers [5], [6]. For this reason, the low performance of students in writing needs urgent attention from lecturers and stakeholders in universities [7], [8].

Various studies state that several factors cause a lack of student writing skills. One of the factors that influence these conditions is the use of learning approaches that are not appropriate [1], [9], [10]. That is, some lecturers are still unable to optimize their learning so that students' writing abilities are below the expected standard [11]. 
Some students stated that they had never been taught to write well before entering college so that they found it difficult to express their ideas and ideas into the written form [12].

To improve the quality of academic writing instruction, one of the ways that can be taken by lecturers is to develop an appropriate learning model. The learning model is a conceptual framework that describes a flow or procedure systematically in managing and organizing learning activities that serve as guidelines for teachers [13]. The learning model contains five primary elements, namely: (1) syntax, (2) social system, (3) principles of reaction, (4) support system, and (5) instructional dan nurturant effects [14], [15].

There need to be aspects that are used as a reference to produce a good learning model. One issue in question is the learning approach. In general, there are three approaches used in writing learning so far, namely a product-based approach, a process-based approach, and a genre-based approach [16]. Because the three methods have their respective weaknesses, the researchers suggest using a combined approach, called the process-genre approach [17]-[19].

One way to develop a writing learning model is to do a needs analysis. Needs analysis is a series of activities carried out to identify and search for information related to initial needs before making improvements or developing a learning product [20], [21]. In writing learning, research on the needs analysis has been carried out by several researchers through various studies [22] [25]. There is no study of needs analysis in writing teaching models that integrate the genre process approach from some of these studies. Besides, the majority of research is more focused on lecturers and experts as research subjects in getting a picture of the needs in the field. For this reason, students and lecturers need to be involved as real learning subjects in the area. The necessity of involving lecturers and students is based on the fact that they are active members in tertiary institutions that need to be included in the process of forming the classroom [26].

There are three problem statements in this study, namely: 1) how are students and lecturers' perceptions related to the importance of academic writing learning models in higher education? 2) how is perception of students and lecturers about the difficulties in academic writing instruction during this time? and 3) how is the perception and expectation of students and lecturers on the study of academic writing in the future?

\section{Literature Review}

\subsection{Need Analysis}

Mitchel [20] states that need analysis is an examination of the needs that exist for training that identifies the performance areas or programs in an organization where the practice is used. In line with Mitchell's statement, Cohen, Manion, and Morrison [21] explained that needs analysis is the activity of identifying problems or needs, which is then followed by the process of identifying objectives, content, implementation, target population, and intervention results.

Another definition states that needs analysis is an activity related to gathering information that will serve as a basis for developing a curriculum in meeting particular learning needs [27]. Requirement analysis is also interpreted as an activity analysis of all objective and subjective information needed to define and validate curriculum goals in a particular institutional context [28].

Needs analysis is considered the most appropriate method because it can inform many things about the nature and content of the target language needs [29]. Thus, the researcher or designer must gather information about the current situation and condition of the student's target[30]. Technically, several techniques can be used in investigating needs, namely questionnaires, observations, interviews, and analysis of authentic written and oral texts [30]-[37].

\subsection{Academic Writing}

Fadda [38] states that academic writing is a mental and cognitive activity because it is a product of the human mind. Mental and cognitive activities are illustrated as an image of someone working alone in a quiet environment. On the other hand, Aydin \& Baysan [39] defined academic writing as a type of writing that begins with determining the problem. This indicates that academic writing needs technical planning and rules.

There are various difficulties and challenges faced by students in the academic writing process. The constraints that are intended include: (1) lack of student confidence in writing, (2) lack of student knowledge about theoretical knowledge and skills in writing, such as creating a writing framework, paraphrasing, and summarizing, and (3) academic writing sometimes expect students to write from expert positions, even when they are not experts in particular topics [38].

Almost similar to the description of Fadda, Bian \& Wang [40] stated that students find it difficult to generate ideas, frame, paraphrase, and summarize their writing activities. Students also experience academic writing difficulties related to inaccurate writing styles, references, and quotes or citations [41].

\subsection{Process-genre Approach}

The type of integrative approach besides the product-process approach is the process-genre approach or process-genre approach. This approach is interpreted as a 
writing activity, which is a blend of process and genre approaches. This approach comes by adopting a process model and genre theory intended as a solvable step of the various limitations in both approaches [9]. That is, the combination of the two approaches will complement each other's shortcomings. [19].

In the process-genre approach, the main point is the activity of writing, which is regulated by the process-genre approach in social situations. That is, an article always has a purpose based on a particular situation [42]. In the process-genre approach, practitioners and researchers find more benefits and advantages compared with their shortcomings. In particular, the stages in the process-genre approach are very complementary because they include language knowledge (product and genre approaches), context and purpose of writing (genre approach), and abilities needed in language use (process approach) [43].

There are several theories in this process-based genre approach. One of them is the theory of genre processes, which says there are six steps in the process-genre approach, namely the stages of preparation, modeling and reinforcing, planning, joint constructing, independent constructing, and revising [44]. Zhao [45] proposed another model in the process-genre approach by simplifying the steps into just four stages, namely: (1) analysis of model texts, (2) independent writing, (3) revising, and (4) editing or proofreading.

\section{Materials and Methods}

\subsection{Research Method}

This research is a qualitative descriptive study using questionnaires and in-depth interviews individually. Qualitative method is a research method that aims to examine the complicated details of a unit, examine the relationship between social events, cultural phenomena \& society through life, experience, behavior, perspectives, perspectives, emotions, and feelings [46], [47]. This method is believed to be able to understand the meaning deeply related to complex phenomena and life processes [48]. This study uses an in-depth study of a small group of people to guide and support the construction of research hypotheses. That is, the results of this qualitative study are descriptive and not predictive [49].

\subsection{Participants}

There are two groups of participants in this study, namely groups of students and lecturers. The student group consisted of 65 first-year students from various faculties at UIN Sultan Maulana Hasanuddin Banten. A next group is a group of lecturers who teach three Indonesian subjects with a minimum of three years of teaching experience. These participants were selected using a purposive random sampling method using predetermined criteria [50]. Purposive sampling aims to choose cases that are rich in information to be able to explain research questions [51].

\subsection{Instruments}

\section{a. Questionnaire}

One of the tools used in this study was a questionnaire. This instrument was adapted from several tools used by previous researchers [49], [52], [53]. This questionnaire has three main focuses, namely: (1) student's language level, (2) student's language problem, and (3) student's language need. This questionnaire consists of 15 questions with answer choices and one essay question (open-ended question): "Write down your suggestions in improving the quality of academic writing learning in Indonesian courses!" Open items added to the final questionnaire aim to clarify the answers. This questionnaire has three main focuses, namely: (1) student's language level, (2) student's language problem, and (3) student's language need. This questionnaire consists of 15 questions with answer choices and one essay question (open-ended question): "Write down your suggestions in improving the quality of academic writing learning in Indonesian courses!” Open items added to the closed questionnaire aim to clarify their answers and establish the validity of the closed questions [54].

\section{b. Semi-structured Interview}

Other instruments used in this study were semi-structured interviews. This type of conversation is widely used within the scope of qualitative research because of several considerations, one of which is because it tends to be flexible [55]. That is, this semi-structured interview can be relied upon to collect data through interview guides that offer the freedom of informants to express their views in their language [56]. This instrument's use is also considered to have the potential to explore personal experiences in-depth and allow researchers to add questions with the aim of the process of clarification and elaboration [57], [58].

The interview process was conducted with three Indonesian lecturers individually to investigate academic learning in writing that was needed and needed by students. Interviews are held in a special room to avoid interfering with the atmosphere outside within 45-60 minutes. Conversations are recorded using a voice recorder with the consent of the respondent.

\subsection{Data Analysis}

The data analysis technique used in this study is the Interactive Analysis model (IA) [59]. IA is a model in producing a systematic representation of a phenomenon or the experience of the participants being studied. IA is based on the premise that those closest to the phenomenon 
under study are the ones who are most suitable for constructing a graphical representation of the effects and results of a system [60]. This model consists of three stages, namely: (1) the data reduction stage, (2) the data presentation stage, and (3) the stage of drawing conclusions or verification.

\section{Results}

\subsection{Questionnaire Results}

Table 1. Student questionnaire results

\begin{tabular}{|l|c|c|c|}
\hline Questioner Question & Answer & $\mathrm{N}$ & $\%$ \\
\hline $\begin{array}{l}\text { Do you like learning } \\
\text { instruction? }\end{array}$ & Really like & 40 & $61.5 \%$ \\
\hline $\begin{array}{l}\text { What are the benefits of } \\
\text { writing instruction? }\end{array}$ & $\begin{array}{c}\text { For a career/ } \\
\text { job }\end{array}$ & 34 & $52 \%$ \\
\hline $\begin{array}{l}\text { Writing learning is as } \\
\text { expected }\end{array}$ & Disagree & 49 & $75 \%$ \\
\hline What did you produce? & Poetry & 52 & $80 \%$ \\
\hline $\begin{array}{l}\text { What is the most challenging } \\
\text { part of writing? }\end{array}$ & Grammar & 40 & $61.5 \%$ \\
\hline $\begin{array}{l}\text { Now an ideal learning model } \\
\text { is needed }\end{array}$ & Strongly agree & 48 & $74 \%$ \\
\hline $\begin{array}{l}\text { Topics that need to be raised } \\
\text { in writing instruction are ... }\end{array}$ & General topics & 35 & $54 \%$ \\
\hline $\begin{array}{l}\text { The main aspect that must be } \\
\text { assessed in writing is ... }\end{array}$ & Writing ideas & 44 & $68 \%$ \\
\hline $\begin{array}{l}\text { What feedback do you } \\
\text { expect? }\end{array}$ & $\begin{array}{c}\text { Discuss } \\
\text { writing }\end{array}$ & 36 & $55 \%$ \\
\hline $\begin{array}{l}\text { It needs to be taught the steps } \\
\text { to write }\end{array}$ & Strongly agree & 41 & $63 \%$ \\
\hline $\begin{array}{l}\text { Do you need to be introduced } \\
\text { to other types of texts? }\end{array}$ & Strongly agree & 39 & $60 \%$ \\
\hline $\begin{array}{l}\text { Should brainstorming be } \\
\text { done in writing instruction? }\end{array}$ & Strongly agree & 35 & $54 \%$ \\
\hline $\begin{array}{l}\text { The need for sample text as a } \\
\text { reference }\end{array}$ & Strongly agree & 56 & $86 \%$ \\
\hline $\begin{array}{l}\text { The writer must know who } \\
\text { the prospective readers of the } \\
\text { text are }\end{array}$ & Agree & 39 & $60 \%$ \\
\hline $\begin{array}{l}\text { Writing results must be } \\
\text { published }\end{array}$ & Strongly agree & 40 & $61.5 \%$ \\
\hline
\end{tabular}

Based on the table above can be obtained information that students like writing instruction. From the total 65 respondents, there were 40 students or $61.5 \%$ who expressed their liking for this learning. They love writing instruction because they assume that the skills will be useful for the future or their future work.

Unfortunately, there was a response from students by $52 \%$ or half of the respondents who claimed that their writing instruction had not been according to what they expected. It indicates that there is something wrong between what they expect and what is happening on the ground. Besides, the grammar aspect is the most challenging aspect for students in this learning. This condition is in line with students' responses to questionnaire questions, which state that they tend to produce more poetry genres than academic styles.

Related to the aspect of writing performance assessment, more students choose aspects of writing ideas as the main aspects that must be assessed in writing activities. This aspect was chosen by students through a questionnaire of $68 \%$. Other aspects, such as grammar, spelling, and choice of words in writing were chosen by respondents with a percentage that is not too large.

In a number of questionnaire questions, the researcher designed several activities characterized as the identity of a particular approach, product-based, process, and genre-based. Writing learning by focusing on examples of text as a reference in writing, stages of writing (prewriting, writing, \& post-writing), and prospective audience (readers) are indications that a combined approach (process-genre approach) is needed by students. Finally, students also considered that the last stage of writing learning was not to collect the results of work to the lecturer but rather to proceed to the publication stage.

In the essay questions (open-ended question) on the questionnaire, the majority of students provide advice and recommendations to eliminate conventional learning strategies. According to them, most teachers only display examples of a text, and then students are asked to write texts with other themes and then collect them. Around $40 \%$ of students stated that after writing was received, teachers usually did not return the text, so they had difficulty identifying deficiencies or errors in their writing. This condition certainly has an impact on learning outcomes that are not effective writing. Birhan [61] emphasized the importance of instructors helping and providing valuable feedback and comments that build and motivate students in writing.

\subsection{Interview Results}

The results of interviews conducted with three lecturers obtained information that they still use conventional approaches in writing instruction. A traditional method is a product-based approach which is identical to learning to write by imitating existing examples of text. "I more often present a sample text then ask students to write by emphasizing some of the elements that must be present in their writing." Usually, the characteristics of a product-based approach begin by presenting an example and then asking students to write by following the pattern of the sample text.

Learning to write using the product approach, of course, must be changed immediately. This is because an approach is a traditional approach that trains students to imitate examples of text that are coherent and error-free in the linguistic aspect [62]. Many experts think that the product approach limits the writer's creativity because the lecturer's sample text bounds it [63] [64]. Also, the approach must be abandoned because it only produces text 
copying activities that are meaningless. [65].

So far, teachers rarely use a process or genre approach, or even a combined approach (process genre). This happens because the teachers consider that the approach requires a relatively long duration of time in teaching. "The 100 minutes allocated at each meeting is felt to be very lacking in teaching academic writing in class.” This argument is inaccurate because the process and genre approach can be made effectively and efficiently [66]. It should also be emphasized that the process-genre approach has many advantages packaged in one package. The process-genre approach is considered superior because it contains several aspects of emphasis in writing, namely: (1) language skills, (2) content knowledge, (3) writing process, and (4) communication emphasis to the audience [67] [68] [69].

All respondents in the interview session stated that learning to write has challenges that are not easy. One of the problems is the difficulty of students in expressing their ideas and ideas into written form. Aunurrahman [70] states that writing is a challenging activity because it includes the exercise of thinking, drafting, and correcting the text. Another factor is the lack of mastery of student vocabulary, so it is difficult to decipher the concept. Another opinion was also expressed by one of the respondents who claimed that the writing process is a process that takes a long time, so it is complicated to achieve instantly and concisely. In essence, the lack of student reading activity is believed to be a determining factor for their lack of vocabulary mastery, making it challenging to develop writing when given a writing assignment.

Regarding suggestions from respondents on future learning to write, many essential points need to be considered by teachers. Some of these points are: (1) the need to add Indonesian language subjects especially for academic writing content, (2) the need for varied and exciting learning approaches to arouse student motivation in writing, (3) aspects of assessment in learning to write must be comprehensively covered all aspects of a paper, and (4) there is a need for the stages of disseminating the final product of writing learning. The four points of advice should receive more attention from the lecturers so that students can write well. The aspects of evaluation, method selection, and publication activities are essential in designing writing learning models. Using interviews and questionnaires, researchers obtained information about the importance of developing writing teaching models by adopting a process-genre approach. On several quizzes and interview questions, the researcher proposes several stages of learning needed in writing. From the results of the needs analysis, the syntax of writing learning is packaged, namely: (1) recognizing the shape of the text, (2) analyzing the structure of the text, (3) discussing the text, (4) writing the text independently, (5) finalizing the text, and (6) publishing text.

\section{Discussion}

As we already know that writing skills are language skills that have a vital role for students. This fact is based on the fact that the campus environment always requires students to be able to write well. The students are well aware that writing skills are needed in finding work in the future [31]. Besides, writing skills are believed to have a role in improving students' literate abilities in writing [71].

From the results of interviews with lecturers and questionnaires to students, it was concluded that the need for an innovative and compelling teaching model improves writing skills. One of them is by implementing a process-genre approach, which is a combination approach from the previous three approaches. The procedures in question are product, process, and genre-based methods. The combination of these three approaches aims to minimize the various deficiencies that exist so that learning objectives can be achieved optimally [16], [45].

The aspect of assessment in learning to write is also an essential aspect that teachers must focus on. The instructor suggests designing an assessment rubric that is not always focused on linguistic elements based on the results of the interview. A matter that is not much different was also stated by previous researchers [54], [55]. The two researchers noted that the assessment of students' academic writings so far tends to use assessment tools in analyzing vocabulary errors only.

In compiling an assessment rubric, instructors refer to various theoretical approaches that focus on discourse and linguistic features and specific rules of academic writing [72]. For this reason, the need for all aspects to be assessed in writing learning which includes: (1) content (relevant ideas), (2) organizing writing (structure and coherence), (3) use of language (vocabulary and grammar choices), and (4) use of mechanical aspects (grammar \& spelling). Thus, students' writing is comprehensively appreciated, and they feel that they have not been harmed by an irrelevant assessment rubric [73].

The majority of respondents expect a stage of publication of the text they produce from the results of interviews and questionnaires. That is, the stages in learning to write do not end at the assessment process conducted by the teacher. Text publications are carried out to inform the reality of the field by providing a truly in-depth perspective [74]. For the academic environment, the importance of publication is needed because it relates to career advancement and the form of professionalism of their work [75], [76].

\section{Conclusions}

This article is a phase of needs analysis in developing an academic writing learning model with a process-genre approach. By using needs analysis, expectations, and a real picture of learning desired by students and lecturers 
can be mapped. Students and lecturers need writing learning that is designed with exciting and innovative steps based on the analysis of needs in this study. One of them is designing learning to write by using a process genre approach. This approach is a combined approach from the three previous methods, which were assessed by experts as having their respective shortcomings, so they need to be combined in minimizing these deficiencies. Other findings relate to the process of evaluating writing learning and writing publications. The lecturers and students need a comprehensive assessment design that focuses not only on grammar and spelling but also on aspects of ideas carried by students. Besides, the publication of writing that has been produced is also an essential step in the writing process. However, the written product produced will not have any effect if it is not disseminated. Dissemination of this article can be done through scientific publication media such as personal blogs, social media, campus bulletins, electronic journals, proceedings, researchgate accounts, osfpreprints, and others.

\section{Acknowledgements}

The authors thank the State Islamic University of Sultan Maulana Hasanuddin Banten, Indonesia, to support this research and the Ministry of Religion of the Republic of Indonesia. It has funded this research through the 5000 Doctoral Scholarship program for 2017.

\section{REFERENCES}

[1] R. Ivanic and M. R. Lea, "New Contexts, New Challenges: The Teaching of Writing in UK Higher Education," in Teaching Academic Writing in UK Higher education: Theories, Practices and Models., Ganobcsik-Williams, Ed. UK: Macmillan Publishing Company, 2006.

[2] R. A. Alabere and A. Shapii, "The Effects of Process-Genre Approach on Academic Writing," JEES (Journal English Educ. Soc., vol. 4, no. 2, pp. 89-98, 2019.

[3] T. Lilis and J. Turner, "Students Writing in Higher Education: Contemporary Confusion, Traditional Concerns," Teach. High. Educ., vol. 6, no. 1, pp. 57-68, 2001.

[4] Helaluddin Helaluddin, "Analisis Kebutuhan dalam Redesain Silabus ( RPS ) Mata Kuliah Bahasa Indonesia di Perguruan Tinggi,” J. Gramatika, vol. 4, no. 1, pp. 85-104, 2018.

[5] K. M. Johnstone, H. Ashbaugh, and T. D. Warfield, "Effects of Repeated Practice and Contextual Writing Experiences on College Students’ Writing Skills,” J. Educ. Psychol., vol. 94, no. 2, 2002.

[6] M. Javed, W. X. Juan, and S. Nazli, “A Study of Students' Assessment in Writing Skills of the English Language," Int.
J. Instr., vol. 6, no. 2, 2013.

[7] J. H. Jahin, "The Effect of Peer Reviewing on Writing Apprehension and Essay Writing Ability of Prospective EFL,” Teach. Aust. J. Teach. Educ., vol. 37, 2012.

[8] T. Sarala, B. I. Fauziah, and B. S. A. Rahim, "Role of Model Essays in Developing Students Writing Skills in malaysian Schools: A Review of Literature,” Mediterranian J. Soc. Sci., vol. 6, no. 56, 2015.

[9] Babalola and H. A. Litinin, "Effects of Process-genre Based Approach on the Written English Performance of Computer Science Students in a Nigerian Polytechnic,” J. Educ. Pract., vol. 3, no. 6, pp. 1-7, 2012.

[10] T. K. Akinwamide, "The Influence of Process Approach in ESL Students Performance in Essay Writing,” J. English Lang. Teach., vol. 5, pp. 16-29, 2012.

[11] N. Heffernan, "An Integrated Approach to Teaching Academic Writing,” Asian EFL J., vol. 8, no. 3, pp. 249-258, 2006.

[12] C. Y. Keong and I. H. Mussa, “Academic Writing Difficulties of Iraqi Postgraduate Students in Malaysia,” Int. J. Educ. Res., vol. 3, no. 6, pp. 25-34, 2015.

[13] T. Tayeb, “Analisis dan Manfaat Model Pembelajaran," Auladuna J. Pendidik. dasar Islam, vol. 4, no. 2, pp. 48-55, 2017.

[14] B. Joyce, M. Weil, and Emily Calhoun, Models of Teaching, Delapan. Yogyakarta: Pustaka Pelajar, 2011.

[15] H. Wijaya and A. Arismunandar, "Pengembangan Model Pembelajaran Kooperatif Tipe STAD Berbasis Media Sosial,” J. Jaffray, vol. 16, no. 2, pp. 175-196, 2018.

[16] R. Badger and G. White, "A process Genre Approach to Teaching Writing,” ELT J., vol. 54, no. 2, pp. 153-160, 2000.

[17] M. Dewle, "Why Genre-based Approach should be Used to Teach Academic Writing in Indian Context?,” J. Chem. Inf. Model., vol. 4, no. 1-9, pp. 1689-1699, 2017.

[18] A. Tesfie, "Teachers' Cognition on Process Genre Approach and Practice of Teaching Writing Skills in EFL Context," English Spesific Purp. World, vol. 54, no. 19, 2017.

[19] R. M. Agibuay, "Descriptive Writing Using the Process-genre Approach,” Asia Pasific J. Contemp. Educ. Commun. Technol., vol. 3, no. 1, 2017.

[20] G. Mitchell, The Trainer's Handbook, The AMMA Guide to Effective Training. New York: AMACOM, 1993.

[21] L. Cohen, L. Manion, and K. Morrison, Research Methods in Education. London: Routledge, 2007.

[22] P. A. Bedoya, L. M. Valencia, and J. C. Montoya, "Students' Needs Analysis in An EFL Program for University Professors,” HOW, vol. 22, no. 2, pp. 11-36, 2015.

[23] K. V.D. Poel, T. V. Dyk, J. Gasiorek, and I. Blockmans, “A Needs Analysis for Communication by Pharmacists in A Multilingual Setting: First Step towards Syllabus and Materials Design,” Stellenbosch Pap. Linguist., vol. 44, pp. 189-212, 2015.

[24] L. J. Cai, “Students’ Perceptions of Academic Writing: A 
Needs Analysis of EAP in China,” Lang. Educ. Asia, vol. 4, no. 1, pp. 5-22, 2013.

[25] S. Sothan, "Exploring English Language Needs According to Undergraduate Students and Employers in Cambodia," Int. J. Linguist. Commun., vol. 3, no. 1, pp. 87-96, 2015.

[26] D. J. Cothran, P. H. Kulinna, and D. A. Garrahy, “This is Kind of Giving a Secret Away: Students' Perspective on Effective Class Management,” Teach. Teach. Educ., vol. 19, no. 4, pp. 435-444, 2003.

[27] J. D. Brown, The Elements of Language Curriculum: A Systematic Approach to Programme Development. Boston: Heinle \& Heinle, 1995.

[28] B. F. Unueshotse, "Needs Analysis of the Writing Skills of HND Business Studies Students at Auchi Polytechnic , Auchi Edo State,” Int. J. English Lit., vol. 8, no. 6, pp. 74-87, 2017.

[29] T. Hutchinson, "Making Materials Work in The ESP Classroom," in ESP in The Classroom: Practice and Evaluation, D. Chamberlain and R. J. Baumgardner, Eds. Oxford: Modern English Publication in association with The British Council, 1988.

[30] T. Dudley-Evans and M. St. Johan, Developments in ESP: A Multidisciplinary Approach. Cambridge: cambridge University Press, 1998.

[31] A. S. E. Mohammed and H. S. M. Nur, "Needs Analysis in English for Academic Purposes: The Case of Teaching Assistants at the University of Khartoum,” How, vol. 25, no. 2, pp. 49-68, 2018.

[32] H. Basturkmen, Developing Courses in Engkish for Spesific Purposes. Basingstoke: Palgrave Macmillan, 2010.

[33] J. D. Brown, "Foreign and Second Language Need Analysis," in The Handbook of Language Teaching, M. H. Long and C. J. Doughty, Eds. London: Wiley-Blackwell, 2009, pp. 269293.

[34] K. Hyland, English for Academic Purposes: An Advanced Resource Book. London: Routledge, 2006.

[35] J. C. Richards, Curriculum Development in Language Teaching. Cambridge: Cambridge University Press, 2001.

[36] C. Graves, Designing Language Courses: A Guided for Teachers. bo: Heinle \& Heinle, 1999.

[37] R. West, "Need Analysis: State The Art," in Teacher Education for Language for Spesific Purposes, G. Brown, Ed. London: Multilingual Matters, 1997, pp. 68-97.

[38] H. Al Fadda, "Difficulties in Academic Writing: From the Perspective of King Saud University Postgraduate Students," English Lang. Teach., vol. 5, no. 3, pp. 123-130, 2012.

[39] G. Aydin and S. Baysan, "Perceptions of postgraduate students on Academic Writing Skills : A Metaphor Analysis Study,” J. Lang. Linguist. Stud., vol. 14, no. 2, pp. 212-239, 2018.

[40] X. Bian and X. Wang, "Chinese EFL Undergraduates' Academic Writing, Rhetorical Difficulties and Suggestions," Indones. J. Appl. Linguist., vol. 6, no. 1, pp. 20-29, 2016.

[41] Aunurrahman, F. A. Hamied, and E. Emilia, "Exploring The
Tertiary EFL Students' Academic Writing Competences,” Indones. J. Appl. Linguist., vol. 7, no. 1, pp. 72-79, 2017.

[42] M. A. Azhar, S. Kiran, and T. Khan, “Teaching Writing Skill Based on Process Genre Approach in Community Learning Context," in Proceedings of SOCIONT 2016 3rd International Conference on Education, Social Science and Humanities, 2016, no. May, pp. 412-417.

[43] N. Pramila, “Approaches to Teaching English Writing: A Research Note," Stud. Foreign Lang. Educ., vol. 39, pp. 141-148, 2017.

[44] S. Agesta and B. Y. Cahyono, "Effect of Process-Genre Approach on the Indonesial EFL Writing Achievement Across Personality,” Int. J. English Lang. Linguist. Res., vol. 5, no. 3, pp. 39-48, 2017.

[45] S. Zhao, "On the Application of The Process-genre Approach to Teaching English Writing,” in 2017 3rd Annual International Conference on Modern Education and Social Science, 2017, pp. 495-499.

[46] J. W. Creswell, Qualitative Inquiry \& Research Design: Choosing among Five Approach. London: Sage, 2007.

[47] H. Helaluddin and H. Wijaya, Analisis Data Kualitatif: Sebuah Tinjauan Teori \& Praktik. Makassar: Sekolah Tinggi Filsafat Jaffray, 2019.

[48] N. K. Denzin and Y. S. Lincoln, Handbook of Qualitative Research. Yogyakarta: Pustaka Pelajar, 2009.

[49] M. B. Ulla and D. Winitkun, “Thai Learners' Linguistic Needs and Language Skills: Implications for Curriculum Development," Int. J. Instr., vol. 10, no. 4, pp. 203-220, 2017.

[50] C. Teddlie and F. Yu, "Mixed Methods Sampling: A Typology with Examples,” J. Mix. Methods Res., vol. 1, no. 1, pp. 77-100, 2007.

[51] I. J. A. Ubah and S. Bansilal, "Pre-service Mathematics Teachers' Knowledge of Mathematics for Teaching: Quadratic Functions,” Probl. Educ. 21st Century, vol. 76, no. 6, pp. 847-863, 2018.

[52] S. A. Boroujeni and F. M. Fard, "A Needs Analysis of English for Specific Purposes (ESP) Course for Adoption of Communicative Language Teaching: (A Case of Iranian First-Year Students of Educational Administration),” Int. $J$. Humanit. Soc. Sci. Invent., vol. 2, no. 6, pp. 35-44, 2013.

[53] T. Hutchinson and A. Waters, English for Spesifik Purpose: A Learning-centered Approach. Cambridge: Cambridge University Press, 1987.

[54] E. Singer and M. P. Couper, "Some Methodological Uses of Responses to Open Questions and Other Verbatim Comments in Quantitative Surveys,” Methods, data, Anal., vol. 11, no. 2, pp. 1-19, 2017.

[55] C. Glensce and A. Penskin, Becoming Qualitatives Researchers: An Introduction. New York: Longman, 1992.

[56] D. Wilkinson and P. Birmingham, Using Research Instruments: A Guide for Researchers. London: RoutledgeFalmer, 2003.

[57] K. H. Guthrie, “'Nothing is Ever Easy’: Parent Perceptions of Intensity in Their Gifted Adolescent Children," Qual. 
Rep., vol. 24, no. 8, pp. 2080-2101, 2019.

[58] W. Percy, K. Kostere, and S. Kostere, “Generic Qualitative Research in Psychology,” Qual. Rep., vol. 20, no. 2, pp. 7685, 2015.

[59] M. B. Miles and A. M. Huberman, An Expanded Sourcebook-qualitative Data Analysis. London: Sage Publications, 1994.

[60] K. Bargate, "Interactive Qualitative Analysis - A Novel Methodology for Qualitative Research,” Mediterr. J. Soc. Sci., vol. 5, no. 20, pp. 11-19, 2014.

[61] Y. Birhan, "Assessment of The Qualities of Academic Writing in Senior Essays of English Graduates: The Case of Dire Dawa University,” Int. J. English Lit., vol. 8, no. 8, pp. 102-114, 2017.

[62] D. Nunan, Second Language teaching and Learning. Cambridge: Cambridge University Press, 1999.

[63] P. G. Pasand and E. B. Haghi, "Process-Product Approach to Writing: the Effect of Model Essays on EFL Learners'Writing Accuracy,” Int. J. Appl. Linguist. English Lit., vol. 2, no. 1, pp. 75-79, 2013.

[64] V. Tuvachit and K. Soontornwipast, “Integrating Adapted Approaches of Writing Instructions with Alternative Assesssment to Improve Academic Writing Ability," Arab World English J., vol. 9, no. 3188-206, 2018.

[65] D. A. Adeyemi, "Approaches to Composition Writing: The Case of junior Secondary Schools in Botswana," Int. J. Learn. Dev., vol. 2, no. 1, pp. 48-64, 2012.

[66] S. Agesta, "Process- Genre Approach : Breaking Students ' Barriers in Writing,” no. 2000, pp. 811-817, 2016.

[67] J. Flowerdew, “An Educational, or Process, Approach to The
Teaching of Professional Genres,” ELT J., vol. 47, no. 4, pp. 3015-316, 1993.

[68] S. M. Nordin and N. Mohammad, "The Best Two Approaches: Process/genre Based Approach to Teaching Writing,” English Teach., vol. 35, no. 1, pp. 75-85, 2006.

[69] K. Yanghee and K. Jiyoung, "Teaching Korean University Writing Class: Balancing the Process and Genre Approach," Asian EFL J., vol. 7, no. 2, pp. 1-15, 2005.

[70] Aunurrahman, F. A. Hamied, and E. Emilia, “Exploring An Academic Writing Class in An Indonesian University Context,” Lang. Circ. J. Lang. Lit., vol. 11, no. 1, pp. 1-12, 2016.

[71] S. Sabarun, "Needs Analysis on Developing EFL Paragraph Writing Materials at Kalimantan L2 learners," English Lang. Teach., vol. 12, no. 1, p. 186, 2019.

[72] H. M. Azimi and R. Rahmani, "Importance of Needs Assessment for Implementation of E-learning in Colleges of Education,” Int. J. Inf. Comput. Technol., vol. 2, no. 12, pp. 377-382, 2013.

[73] Helaluddin, H, “Analisis Struktur Esai Mahasiswa pada Mata Kuliah Bahasa Indonesia di IAIN Sultan Maulana Hasanuddin Banten,” Bind. Sastra, vol. 1, no. 1, pp. 15-23, 2017.

[74] T. L. Smiles and K. G. Short, "Transforming Teacher Voice through Writing Publication,” Teach. Educ. Q., vol. 33, no. 3, pp. 133-147, 2006.

[75] M. Derntl, "Basics of Paper Writing and Publishing,” Int. J. Technol. Enhanc. Learn., vol. 6, no. J2, pp. 105-123, 2014.

[76] M. L. Cárdenas, "Publishing and Academic Writing: Experiences of Authors Who Have Published in PROFILE," PROFILE, vol. 16, no. 2, pp. 11-20, 2014. 